\title{
Upaya Peningkatan Motivasi Belajar Lari Jarak Pendek melalui Metode Bermain pada Siswa Kelas V Sekolah Dasar
}

\author{
Titi Suwarti* \\ SD Negeri 2 Mlese Kecamatan Gantiwarno Kabupaten Klaten \\ *suwartititi@gmail.com
}

\begin{abstract}
Short distance learning in Mlese Gantiwarno Public Elementary School 2 in Klaten, which is monotonous, makes students feel bored so that the process and achievement of learning outcomes are less than optimal. This study aims to determine the increase in motivation to learn short distance running in fifth grade students of SD Negeri 2 Mlese Gantiwarno Klaten Semester II 2017/2018 Academic Year through the method of playing. This research is a Classroom Action Research. The subjects in this study were fifth grade students of SDN 2 Mlese, Gantiwarno District, Klaten Regency, which amounted to 20 students. The data collection technique uses observation sheets to determine student interest, motivation questionnaires, and student performance sheets. The results showed that the average score of the aspects of interest was 76.35 so that the average interest of students had exceeded 70 , thus the interest of students had increased. The performance aspects of students showed an average value of 72.95, this indicates that the value of students has achieved a minimum of completeness, namely 70 , so that the target of $70 \%$ of students completed has been fulfilled. Based on the motivation questionnaire shows that $64.1 \%$ of children have good motivation. The fifth grade students of SD Negeri 2 Mlese in each cycle experienced an increase and by giving the method of playing students felt happy or felt interested in taking short distance learning. So that learning through the method of playing approach in short distance running material in class V students of SD Negeri 2 Mlese has succeeded in increasing students' motivation and learning achievement in following the learning.
\end{abstract}

\begin{abstract}
Abstrak: Pembelajaran lari jarak pendek di SD Negeri 2 Mlese Gantiwarno Klaten yang monoton membuat siswa-siswi merasa bosan sehingga proses dan pencapaian hasil pembelajaran kurang optimal. Penelitian ini bertujuan untuk mengetahui peningkatan motivasi belajar lari jarak pendek pada siswa kelas V SD Negeri 2 Mlese Gantiwarno Klaten Semester II Tahun Pelajaran 2017/2018 melalui metode bermain. Penelitian ini merupakan Penelitian Tindakan Kelas. Subyek dalam penelitian ini adalah siswa kelas V SD Negeri 2 Mlese Kecamatan Gantiwarno Kabupaten Klaten yang berjumlah 20 siswa. Teknik pengambilan data menggunakan lembar observasi untuk mengetahui minat siswa, angket motivasi, dan lembar unjuk kerja siswa. Hasil penelitian menunjukan bahwa skor rata-rata kelas dari aspek minat adalah 76,35 sehingga rata-rata minat siswa sudah melebihi 70, dengan demikian minat siswa mengalami peningkatan. Aspek unjuk kerja siswa menunjukkan nilai rata-rata 72,95, hal ini menunjukkan bahwa nilai siswa telah mencapai ketuntasan minimal yaitu 70 , sehingga target $70 \%$ siswa tuntas sudah terpenuhi. Berdasarkan angket motivasi menunjukkan bahwa $64,1 \%$ anak memiliki motivasi yang baik. Siswa kelas V SD Negeri 2 Mlese pada setiap siklus mengalami peningkatan dan dengan pemberian metode bermain siswa siswi merasa senang atau merasa tertarik untuk mengikuti pembelajaran lari jarak pendek. Sehingga pembelajaran melalui metode pendekatan bermain pada materi lari jarak pendek pada siswa kelas V SD Negeri 2 Mlese telah berhasil meningkatkan motivasi dan prestasi belajar siswa dalam mengikuti pembelajaran.
\end{abstract}

Kata Kunci: motivasi belajar, lari jarak pendek, metode bermain. 


\section{Pendahuuan}

Pendidikan adalah usaha dasar yang terencana untuk mewujudkan suasana belajar dan pembelajaran agar siswa secara aktif mengembangkan potensi dirinya untuk memiliki kekuatan spiritual keagamaan, pengendalian diri, kecerdasan, kepribadian, akhlak mulia, serta keterampilan yang diperlukan dirinya dan masyarakat. Pendidikan meliputi pengajaran keahlian khusus dan juga sesuatu yang tidak dapat dilihat dan masyarakat. Pendidikan meliputi pengajaran keahlian khusus dan juga sesuatu yang tidak dapat dilihat tetapi lebih mendalam yaitu pemberian pengetahuan, pertimbangan dan kebijaksanaan. Salah satu dasar utama pendidikan adalah untuk mengajar kebudayaan melewati generasi.

Dalam realitas kehidupan, sebgai kondisi nyata proses pendidikan, dapat dilihat dengan adanya perubahan sosial yang begitu cepat, proses transformasi budaya yang semakin deras, juga perkembangan politik, kesenjangan ekonomi yang semakin melebar serta peregseran nilai kemanusiaan, mengharuskan pendidikan memfokuskan sasarannya ke arah ini. Oleh karena itu pendidikan harus senantiasa toleran dan fleksibel pada perubahan normatif dan kultural yang terjadi di masyarakat.

Salah satu yang tak boleh dipisahkan dari sistem pendidikan nasional adalah pendidikan jasmani, bertujuan mengembangkan aspek kesehatan, kebugaran jasmani, keterampilan berfikir kritis, stabilitas emosional, keterampilan sosial, penalaran, dan tindakan moral melalui kegiatan jasmani dan olah raga. Pendidikan jasmani merupakan salah satu mata pelajaran yang wajib diajarkan di sekolah. Pendidikan jasmani berperan penting dalam pembinaan dan pengembangan baik individu maupun kelompok dalam menunjang pertumbuhan serta perkembangan jasmani dan rohani. Pendidikan jasmani pada dasarnya merupakan bagian intregal dari sistem pendidikan secara keseluruhan, bertujuan untuk mengembangkan aspek kesehatan, kebugaran jasmani, keterampilan befikir kritis, stabilitas emosional, keterampilan sosial, penalaran dan tindakan moral melalui aktivitas jasmani dan olahraga. Aktivitas jasmani dan olahraga di sekolah terdiri dari beberapa cabang olahraga yang telah dicantumkan dan dijabarkan dalam silabus. Beberapa cabang olahraga yang sering muncul adalah permainan bola besar yang terdiri dari bolavoli, bolabasket, dan sepakbola. Cabang olahraga atletik juga berperan dalam pendidikan jasmani olahraga dan kesehatan diantaranya nomor lompat dan nomor lari yang terdiri dari lari jarak jauh, larijarak menengah, dan lari jarak pendek.

Atletik merupakan aktivitas jasmani yang terdiri dari gerakan-gerakan dasar yang dinamis dan harmonis, yaitu jalan, lari, lompat, dan melempar. Atletik juga merupakan sarana untuk pendidikan jasmani dalam upaya meningkatkan kemampuan biomorik, misalnya kekuatan, dayatahan, kecepatan, kelenturan, koordinasi. Dalam cabang olahraga atletik ada tiga nomor yang sering di perlombakan, yaitu nomor : jalan dan lari, nomor lompat, dan nomor lempar. Dalam cabang olahraga atletik khususnya lari, di sekolah menengah pertama saat ini diulas kembali mata pelajaran lari jarak pendek, yang dulu pernah di ajarkan ketika masih sekolah dasar. Dan materi yang di sapaikan adalah nomor Lari jarak pendek $50 \mathrm{~m}$, lari $50 \mathrm{~m}$ merupakan salah satu unsur nomor atletik yang wajib diajarkan pada siswa Sekolah Menengah Pertama, karena Atletik juga merupakan sarana bagi pendidikan jasmani peserta didik dalam upaya meningkatkan daya tahan, kekuatan, kecepatan, kelincahan.

Lari jarak pendek merupakaan salah satu nomor dalam cabang olahraga atletik. Menurut Eddy Purmono, (2011: 32) lari jarak pendek adalah lari yang menempuh jarak antara 50 meter sampai dengan jarak 400 meter. Lari jarak pendek merupakan materi pembelajaran yang tidak banyak digemari oleh siswa. Oleh karena itu biasanya siswa kurang bersemangat dalam mengikuti pembelajaran lari jarak pendek, sehingga hasil pembelajarannya pun kurang maksimal. Padahal dalam penilaian biasanya guru akan lebih memperhatikan hasil belajar siswa. Guru akan memberikan nilai lebih kepada siswa yang dapat menguasai teknik lari jarak pendek dengan baik.

Menurut Eddy Purnomo dan Dapan (2011: 33) lari jarak pendek bila dilihat dari beberapatahap, yaitu:

1) Tahap reaksi dan dorongan (reaction dan drive)

2) Tahap percepatan (acceleration)

3) Tahap transisi/ perobahan (transition) 
4) Tahap kecepatan maksimum (speed maximum)

5) Tahap pemeliharaan kecepatan (maintenance speed)

6) Finish

Dalam lari jarak pendek dikenal berbagai teknik, diantaranya :

a. Teknik srart

Start adalah suatu persiapan awal seorang pelari akan melakukan gerakan berlari. Nomor lari jarak pendek, start yang dipakai adalah start jongkok (Crouch Start) sedangkan untuk jarak menengah dan jauh menggunakan start berdiri (Standing Start). Seorang pelari harus benarbenar memperhatikan sikap dan cara melakukan start yang baik, karena start merupakan bagian utama dalam lari selain kecepatan dan teknik lari. Start merupakan awalan bagi pelari sebelum melakukan lari, oleh karena itu seorang pelari harus menguasai dan dapat melakukan teknik start dengan baik untuk mencapai prestasi yang optimal.

b. Teknik Posisi "Bersedia"

Menurut Sunaryo Basuki (1979: 59) "pada saat aba aba "Bersedia", pelari maju kemuka garis start, kemudian melangkah mundur untuk menempatkan kaki, bertumpu pada start block. Kaki yang terkuat di tempatkan di depan (biasanya kaki kiri) berlutut (lutut kaki belakang di letakan di tanah, lutut kaki depan bergantung lemas). Bersihkan tangan, letakan tangan tepat di belakang garis start.

Sejalan dengan Eddy Purnomo dan Dapan (2011:26). Setelah starter memberikan "aba-aba Bersedia", maka pelari akan menempatkan kedua kaki dalam menyentuh block depan dan belakang; lutut kaki belakang di letakkan di tanah terpisah selebar bahu lebih sedikit, jari jari tangan membentuk huruf $\mathrm{V}$ terbalik, dan kepala dalam keadaan datar dengan punggung, sedangkan pandangan mata menatap lurus kebawah.

c. Teknik Posisi "Siap"

Menurut Edy Purnomo dan dapan (2011: 27) menyatakan bahwa : setelah aba-aba siap, seorang pelari akan menentukan posisi badan sebagai berikut: lutut ditekuk ke belakang, lutut kaki depan ada dalam posisi membentuk sudut siku-siku $\left(90^{\circ}\right)$ lutut kaki belakang membentuk sudut antara $120^{\circ}-140^{\circ}$ dan pinggang sedikit diangkat tinggi dari bahu, tubuh sedikit condong ke depan, serta bahu sedikit lebih maju ke depan dari kedua tangan.

d. Teknik Posisi "Yaak"

Gerakan yang akan dilakukan oleh pelari setelah aba-aba Yaak/ bunyi pistol adalah badan diluruskan dan diangkat pda saat kedua kaki menolak/ menekan keras pada straf-block; kedua tangan diayun bergantian; kaki belakang mendorong kuat/ singkat, dorong kaki depan sedikit tidak namun lebih lama; kaki depan diayun ke belakang dengan cepat sedangkan badan condong ke depan; lutut dan pinggang keduanya diluruskan penuh pada saat akhir dorongan.

e. Teknik Berlari

Teknik berlari merupakan unsur gerakan yang dapat menunjang pelari agar dapat mencapai kecepatan kecepatan yang maksimal dan prestasi yang bagus.

f. Teknik Memasuki Garis Finish

Memasuki garis finish adalah fase akhir penentu menang atau kalahnya seorang sprinter. Teknik memasuki garis finish sangat penting untuk dipahami dan dikuasai oleh sprinter, sebab meski mempunyai kekuatan dan kecepatan bila teknik memasuki garis finish dari sprinter tidak baik, bisa menyebabkan kekalahan. Seorang sprinter bebas menentukan dengan cara ataupun teknik sendiri melewati garis finish yang dianggap paling efektif dan efisien.

Materi lari jarak pendek ini meliputi cara melakukan start, saat berlari dan cara melewati garis finis. Metode yang di gunakan dalam mengajar menggunakan metode klasikal seperti yang biasa digunakan oleh guru Pendidikan Jasmani Olahraga dan Kesehatan di tingkat SMP yaitu guru menjelaskan materi secara keseluruhan kemudian menyuruh siswa untuk mempraktikkan langsung secara berulang-ulang, selanjutnya guru hanya mengamati serta memberikan pengarahan ketika siswa melakukan kesalahan. Namun penyampaian materi pelajaran yang seperti itu membuat siswasiswi terlihat kurang bersemangat ketika mendapat materi pelajaran lari jarak pendek. Kebanyakan siswa mengaku tidak suka dan malas mengikuti pelajaran lari jarak pendek, bahkan ada siswa yang 
meminta untuk mengganti dengan materi pelajaran lainnya. Siswa-siswi sulit diarahkan ketika mengikuti pembelajaran atletik lari jarak pendek, tidak terlihat seperti saat diajarkan materi permainan bolavoli ataupun sepakbola.

Motif adalah daya pendorong atau tenanga pendorong yang mendorong manusia untuk bertindak atau suatu tenaga didalam diri manusia yang mendorong manusia bertindak. Sedangkan motivasi sendiri adalah faktor yang mendorong seseorang bertindak dengan cara tertentu. Dengan demikian, dapat dikatakan bahwa motivasi pada dasarnya adalah kondisi mental yang mendorong dilakukan suatu tindakan dan memberikan kekuatan yang mengarah kepada pencapaian kebutuhan, memberi kepuasan, ataupun mengurangi ketidak seimbangan.

Menurut Ratna Yudhawati \& danyharyanto (2011: 88) Motivasi seseorang individu sangat dipengaruhi oleh berbagai faktor, baik yang bersifat internal maupun eksternal. Termasuk pada faktor internal adalah; (a) Persepsi seseorang mengenai diri sendiri, (b) Harga diri, (c) Keinginan kepuasan kerja, (f) Prestasi kerja yang dihasilkan. Sedangkan faktor eksternal memperngaruhi motivasi seseorang antara lain ialah; (a) jenis dan sifat pekerjaan, (b) Kelompok kerja dimana seseorang bergabung,(c) Organisme sempat kerja, (d) Situasi lingkungan pada umumnya, (d) system imbalan yang berlaku dan cara penerapannya.

Berdasarkan uraian para ahli diatas, peneliti dapat mengambil kesimpulan bahwa motivasi adalah dorongan, penggerak atau alasan orang untuk berperilaku, bertindak, berkelakuan yang merupakan kekuatan yang bersumber pada keinginan individudalm mencapai kebutuhan atau tujuan-tujuan hidupnya. Munculnya motivasi, maka individu akan mempunyai semangat untuk melakukan segala aktifitas dalam mencapai kebutuhannya baik motivasi itu dari diri sendiri maupun dari luar individu.

Pada dasarnya motivasi olahraga dibagi dalam dua macam yaitu:

1) Motivasi Instrinsik

Motivasi Instrinsik adalah motivasi yang ada pada diri dalam diri sendiri, contohnya seorang olahragawan melakukan olahrga demi menjaga atau memelihara kebugarannya dan kesehatannya.

2) Motivasi Ekstrinsik

Motivasi berolahraga bagi anak-anak, remaja dan para orang tua yang tidak mempersiapkan diri untuk pertandingan antara lain:

a) Untuk bersenang-senang mendapatkan kegembiraan.

b) Untuk melepaskan ketengangan psikis.

c) Untuk mendapatkan pengalaman.

d) Untuk menambah teman.

e) Untuk memelihara kebugaran jasmani.

Siswa-siswi lebih pasif dan banyak mengeluh karena merasa pelajarannya membosankan. Dari faktor lingkungan pun ketika pembelajaran lapangan yang digunakan berbagi dengan kelas lain, sehingga pembelajaran kurang maksimal. Keadaan tersebut mempengaruhi hasil belajar siswa yang menyebabkan ketuntasan belajar siswa kurang maksimal. Hal tersebut dibuktikan dengan ketuntasan belajar hanya mencapai $40 \%$, sehingga guru harus mengadakan remidi untuk mencapai kriteria kelulusan minimal (KKM) 70. Perlu langkah pemecahan yang harus dilakukan untuk meningkatkan motivasi siswa kelas V SD Negeri 2 Mlese Kecamatan Gantiwarno Kabupaten Klaten dalam mengikuti pembelajaran lari jarak pendek sehingga akan memperoleh hasil pembelajaran yang optimal. Salah satunya dengan metode remidial, remidial sendiri adalah upaya untuk perbaikan pada pembelajaran yang di tujukan kepada anak-anak yang mengalami hambatan dalam proses pembelajaran. Menurut dari Sri Hastuti (1992: 4) tujuan remidial adalah ingin membantu anak didik mengatasi kesulitan belajar, tanpa mempertimbangkan jenis, jumlah dan sifat masalah yang menghambatnya.

Menurut Ross \& stanley (1956) dalam buku Sri Hastuti (1992: 7) tindakan strategis dalam konteks dasar diagnostik dan pengajaran remidial, seyogyanya dilakukan secara kuratif (penyembuhan) dan preventif (pencegahan).

1) Strategi dan teknik pendekatan pengajaran/program remidial yang kuratif. 
Strategi macam ini berkaitan dengan PBM (Proses Belajar Mengajar). Kalau program PBM telah diselenggarakan, lazimnya secara kelompok atau klasikal ada beberapa siswa memperlihatkan ketidakmampuannya enyelesaikan tugas-tugasnya. Siswa-siswi itu adalah:

a) Siswa yang prestasinya ada dibatas kriterianya keberhasilan minimal dan

b) Siswa yang sedikit masih kurang atau sebaliknya lebih tinggi sekalipun prestasinya dari ukuran kriteria keberhasilan minimal; dengan kata lain prestasinya masih lemah. Oleh para ahli untuk membantu siswa yang tergolong dalam a dan b diterapi dengan dengan pendekatan yang dikenal dengan pengulangan (repetition), pengayaan (enrichment)dan penguatan (reinforcement) serata percepatan (acceleration).

2) Srategi dan teknik pendekatan pengajaran/program remidial yang preventif.

Srategi macam ini hanya ditujukan kepada siswa yang secara empirik, yang berdasarkan data diprediksikan (diramalkan) akan mengalami kesulitan dalam program studi tertentu yang ditempuhnya. Oleh karena itu, pendekatan preventif selalu berupaya agar siswa selalu mampu mencapai prestasi dan mampu menyelesaikan dengan kriteria keberhasilan yang ditetapkan.

Jadi kesipulan dari teori-teori di atas dapat disimpulkan bahwa metode dengan pendekatan remidial adalah upaya meningkatkan pada prestasi belajar pada siswa siswi agar mampu menyelesaikan keberhasilan yang ditetapkan. Pendekatan bermain merupakan salah satu metode yang sering digunakan dan terbukti mampu meningkatkan motivasi siswa dalam mengikuti pembelajaran. Sehingga pendekatan bermain juga dapat digunakan dalam upaya meningkatkan motivasi pembelajaran lari jarak pendek, namun belum diketahui tingkat keberhasilan terhadap peningkatan motivasi pembelajaran pada siswa Kelas V SD Negeri 2 Mlese, serta belum pernah diadakan penelitian terkait terhadap siswa kelas V SD Negeri 2 Mlese. Maka dari itu untuk mengetahuhi peningkatan motivasi pembelajaran lari jarak pendek pada siswa kelas V SD Negeri 2 Mlese, perlu dikaji dan diteliti lebih dalam melalui penelitian yang berjudul, "Upaya Peningkatan Motivasi Belajar Lari Jarak Pendek Melalui Metode Bermain Pada Siswa Kelas V SD Negeri 2 Mlese Kecamatan Gantiwarno Kabupaten Klaten Semester II Tahun Pelajaran 2017/ 2018.

Menurut Hurlock (1991: 320) yang di kutip dari M. Furqon Hadayatullah (2006 : 2) bahwa "Bermain adalah setiap kegiatan yang dilakukan untuk kesenangan yang di timbulkannya, tanpa mempertimbangkan hal akhir" [11]. Bermain dapat memberikan pengalaman belajar yang sangat berharga untuk peserta didik dalam membina hubungan dengan teman sesama dan menyalurkan bakat peserta didik.

Pembelajaran dengan model bermain diharapkan proses pembelajaran lari jarak pendek mempunyai manfaat dan memberikan pengalaman belajar bagi siswa sehingga akan dapat terjadi perbaikan minat, motivasi belajar dan terutama partisipasi peserta didik dalam pembentukan gerak dasar teknik-teknik lari jarak pendek.

Berdasarkan latar belakang di atas, hipotesis dalam penelitian ini adalah " Motivasi belajar lari jarak pendek pada siswa kelas V SD Negeri 2 Mlese Kecamatan Gantiwarno Kabupaten Klaten Semester II Tahun Pelajaran 2017/2018 dapat ditingkatkan melalui metode bermain". Berdasarkan hipotesisi di atas, tujuan yang ingin dicapai dalam penelitian ini yaitu untuk mengetahui peningkatan motivasi belajar lari jarak pendek pada siswa kelas V SD Negeri 2 Mlese Gantiwarno Klaten Semester II Tahun Pelajaran 2017/2018 melalui metode bermain.

\section{Metode Penelitian}

Penelitian ini akan dilaksanakan di SD Negeri 2 Mlese Kecamatan Gantiwarno Kabupaten Klaten dengan subyek penelitian adalah seluruh siswa kelas V semester II tahun pelajaran 2017/2018. Pelaksanaan penelitian direncanakan pada semester II tahun pelajaran 2017/2018 selama 2 bulan dengan direncanakan mulai dari Februari 2018 hingga bulan Maret 2018 dengan menyesuaikan jam pelajaran olahraga kelas tersebut.

Sumber data dalam Penelitian Tindakan Kelas (PTK) ini adalah sebagai berikut :

1. Siswa, untuk mendapatkan data tentang motivasi lari jarak pendek siswa melalui metode bermain pada siswa kelas V SD Negeri 2 Mlese. 
2. Guru, sebagai kolaborator, untuk melihat tingkat keberhasilan penerapan metode bermian dalam pembelajaran lari jarak pendek di kelas V SD Negeri 2 Mlese Gantiwarno Klaten semester II tahun pelajaran 2017/2018.

Tujuan yang ingin dicapai dalam penelitian ini adalah meningkatkan motivasi belajar lari jarak pendek siswa kelas V SD Negeri 2 Mlese Gantiwarno Klaten semester II tahun pelajaran 2017/2018. Adapun setiap tindakan upaya untuk pencapaian tujuan tersebut dirancang dalam satu unit sebagai satu siklus. Setiap siklus terdiri dari empat tahap, yaitu : perencanaan tindakan, pelaksanaan tindakan, observasi dan interpretasi, analisis dan refleksi untuk perencanaan siklus berikutnya. Penelitian ini direncanakan dalam dua siklus.

\section{Hasil dan Pembahasan}

a. Hasil Penelitian

1) Pengamatan Lembar Observasi Siklus 1

Hasil penelitian aspek minat pada siklus I dideskripsikan menggunakan analisis statistik deskriptif sebagai berikut, nilai minimal $=33$, nilai maksimal $=100$, rata-rata (mean) $=62,39$, nilai tengah $($ median $)=67$, nilai sering muncul $($ modus $)=67$.

Hasil penelitian aspek unjuk kerja pada siklus I dideskripsikan menggunakan analisis statistik deskriptif sebagai berikut, nilai minimal $=40$, nilai maksimal $=55$, rata-rata (mean) $=47,76$, nilai tengah $($ median $)=48$, nilai sering muncul $($ modus $)=49$.

Sedangkan analisis motivasi siswa pada siklus I semua siswa mendapat skor 37 dan ini menunjukkan bahwa skor tersebut masih tergolong sangat minim. Artinya motivasi siswa pada siklus I masih kurang.

2) Pengamatan Lembar Observasi Siklus II

Hasil penelitian aspek minat pada siklus II dideskripsikan menggunakan analisis statistik deskriptif sebagai berikut, nilai minimal $=33$, nilai maksimal $=100$, rata-rata (mean) $=70,94$, nilai tengah $($ median $)=67$, nilai sering muncul $($ modus $)=67$.

Hasil penelitian aspek unjuk kerja pada siklus II dideskripsikan menggunakan analisis statistik deskriptif sebagai berikut, nilai minimal $=56$, nilai maksimal $=74$, rata-rata (mean) $=62,63$, nilai tengah $($ median $)=64$, nilai sering muncul $($ modus $)=64$.

Sedangkan analisis motivasi siswa pada siklus II nilai minimal $=56$, deskripsi menggunakan analisis deskripsi sebagai berikut, nilai maksimal $=76$, rata-rata $($ mean) $=$ 65,87 , nilai tengah $($ median $)=66$, nilai sering muncul $($ modus $)=69$.

3) Pengamatan Lembar Observasi Siklus III

Hasil penelitian aspek minat pada siklus III dideskripsikan menggunakan analisis statistik deskriptif sebagai berikut, nilai minimal $=33$, nilai maksimal $=100$, rata-rata (mean) $=76,35$, nilai tengah $($ median $)=78$, nilai sering muncul $($ modus $)=78$.

Hasil penelitian aspek unjuk kerja pada siklus III dideskripsikan menggunakan analisis statistik deskriptif sebagai berikut, nilai minimal $=65$, nilai maksimal $=80$, rata-rata (mean) $=72,95$, nilai tengah $($ median $)=74$, nilai sering muncul $($ modus $)=75$.

Sedangkan analisis motivasi siswa pada siklus III nilai minimal $=56$, deskripsi menggunakan analisis deskripsi sebagai berikut, nilai maksimal $=80$, rata-rata (mean) $=76$, nilai tengah $($ median $)=68$, nilai sering muncul $($ modus $)=69$.

b. Pembahasan

1) Siklus I

Bedasarkan pembahasan penelitian menunjukkan bahwa pembelajaran pada Siklus I hasil skor rata-rata kelas dari aspek Minat adalah 62,39. menunjukkan aspek minat siswa masih kurang. Dan pada aspek unjuk kerja 100\% siswa kelas V SD Negeri 2 Mlese belum mengalami ketuntasan sedangakan pada aspek motivasi siswa $100 \%$ juga kurang meminati pembelajaran lari jarak pendek. Dikarenakan ketika pembelajaran siswa masih sering bermain sendiri, siswa kurang memperhatikan penjelasan dari guru, masih banyak juga siswa yang keluyuran dan berbicara dengan temannya, dan proses pembelajaran kurang menarik dan kurang kreatif untuk siswa. Hal ini menunjukkan bahwa pembelajaran pada 
pertemuan pertama masih berada di bawah nilai kriteria ketuntasan minimal. Kriteria ketuntasan minimal yang ditetapkan untuk mata pelajaran Penjasorkes adalah 70, selain itu dapat diketahui bahwa 100\% atau seluruh siswa kelas V SD Negeri 2 Mlese memiliki nilai dibawah KKM.

Dari semua hasil analisis diatas menunjukkan bahwa hasil dari pembelajaran pada pertemuan pertama masih sangat jauh dari yang diharapkan, sehingga perlu diberikan pembelajaran pada pertemuan kedua dengan dengan metode pendekatan yang lebih efektif lagi.

2) Siklus II

Pada Siklus II bahwa hasil skor rata-rata kelas dari aspek minat adalah 70,94. Menunjukkan bahwa hasil pembelajaran pada Siklus I ke Siklus II telah mengalami peningkatan sebesar 8,1 (dari 62,39 menjadi 70,49). Akan tetapi mayoritas siswa masih memiliki minat kurang sekali sebesar 30\% sehingga secara klasikal target belum terpenuhi meski telah mengalami peningkatan. Sedangkan pada aspek unjuk kerja nilai rata-rata kelas adalah 62,63. Hal ini menunjukkan bahwa hasil pembelajaran pada Siklus I ke Siklus II telah mengalami peningkatan sebesar 14,87 (dari 47,76 menjadi 62,63). Akan tetapi nilai siswa masih berada di bawah nilai kriteria ketuntasan minimal. Kriteria ketuntasan minimal yang ditetapkan untuk mata pelajaran Penjaskes adalah 70, selain itu dapat diketahui bahwa baru sebesar 5\% siswa memiliki nilai unjuk kerja lebih dari 75 dan siswa yang kurang memiliki nilai kurang dari 70 sebanyak 95\%, sehingga target $75 \%$ siswa tuntas belum terpenuhi. Berdasarkan angket motivasi yang diberikan kepada siswa pada Siklus II ini menunjukkan bahwa $60 \%$ anak memiliki motivasi yang yang meningkat dan baik, artinya dilihat dari segi motivasi siswa telah menjadi lebih baik. Dari pembahasan diatas dapat diketahui bahwa pada setiap aspek mengalami peningkatan yang baik, akan tetapi dari hasil peningkatan tersebut belum memenuhi nilai ketuntasan minimal yaitu 70. Dikarenakan siswa masih belum paham dengan model pembelajaran dengan metode bermain, siswa masih sering bertanya, guru terlalu cepat ketika memberikan penjelasan tentang materi lari jarak pendek, dan masih juga ada siswa- siswi yang bermain sendiri, siswa kurang memperhatikan penjelasan dari guru, masih banyak juga siswa yang keluyuran dan berbicara dengan temannya, dan proses pembelajaran masih kurang menarik dan masih kurang kreatif.

Dari semua hasil analisis diatas menunjukkan bahwa hasil dari pembelajaran pada Siklus II masih belum semuanya seperti yang diharapkan maka perlu adanya pembenahan pada metode bermain agar siswa siswi merasa tertarik dan merasa termotivasi dengan pembelajaran lari jarak pendek. Sehingga perlu diberikan pembelajaran pada pertemuan ketigadengan lebih kreatif dan kondusif lagi. Supaya kriteria ketuntasan minimal 70 terpenuhi.

\section{3) Siklus III}

Pada Siklus III hasil skor rata-rata kelas dari aspek minat adalah 76,35. Menunjukkan bahwa hasil pembelajaran pada Siklus III menunjukkan peningkatan sebesar 5,41 (siklus II : 70,94 dan siklus II : 76,35) bahwa rata-rata minat siswa sudah melebihi 70 . Selain itu mayoritas siswa memiliki minat yang telah mencapai target yakni sebesar $35 \%$ memiliki minat baik sekali sehingga secara klasikal target telah terpenuhi dan telah mengalami peningkatan. Sedangkan pada aspek unjuk kerja nilai rata-rata kelas adalah 72,95 dibanding dengan Siklus II mengalami peningkatan sebesar 10,32 (dari 62,63 menjadi 72,95). selain itu dapat diketahui bahwa sebesar $80 \%$ siswa memiliki nilai unjuk kerja lebih dari 70 , sehingga target $75 \%$ siswa tuntas sudah terpenuhi. Berdasarkan angket motivasi yang diberikan kepada siswa pada siklus III ini menunjukkan bahwa 60\% anak memiliki motivasi yang baik, artinya dilihat dari segi motivasi siswa telah terpenuhi. Pada dasarnya siswa kelas V SD Negeri 2 Mlese pada setiap siklus mengalami peningkatan dan 
dengan pemberian metode bermain siswa merasa senang atau merasa tertarik untuk mengikuti pembelajaran lari jarak pendek.

Dari semua hasil analisis diatas menunjukkan bahwa hasil dari pembelajaran pada Siklus III semua aspek target pembelajaran telah sesuai seperti yang diharapkan. Sehingga pembelajaran menggunakan metode pendekatan bermain pada materi lari jarak pendek pada siswa kelas V SD Negeri 2 Mlese telah berhasil meningkatkan motivasi dan prestasi belajar siswa dalam mengikuti pembelajaran.

\section{Kesimpulan}

Siswa kelas V SD Negeri 2 Mlese pada setiap siklus mengalami peningkatan dan dengan pemberian metode bermain siswa siswi merasa senang atau merasa tertarik untuk mengikuti pembelajaran lari jarak pendek. Sehingga pembelajaran melalui metode pendekatan bermain pada materi lari jarak pendek pada siswa kelas V SD Negeri 2 Mlese telah berhasil meningkatkan motivasi dan prestasi belajar siswa dalam mengikuti pembelajaran. 